\title{
ANGKUTAN UMUM KENDARAAN BERMOTOR RODA DUAMENURUT UNDANG-UNDANG LALU LINTAS DAN ANGKUTAN JALAN
}

\author{
Oleh : \\ Prihatin Effendi*, Yonifan Theo Widiabriade** \\ *Fakultas Hukum, Universitas Gresik \\ Email : peffendi5@gmail.com \\ **Fakultas Hukum Universitas Gresik \\ Email: yonifantheo@gamil.com
}

\begin{abstract}
ABSTRAK
Penggunaan sepeda motor sebagai sarana angkutan umum tengah menuai pro dan kontra di tengah masyarakat, karena dinilai sangat diminati oleh masyarakat, akan tetapi juga dianggap bermasalah karena tidak ada regulasi yang jelas dan tegas terkait penggunaan sepeda motor sebagai angkutan umum. Maka dari kondisi permasalahan diatas, Penulis ingin mengetahui keabsahan secara hukum terkait penggunaan sepeda motor sebagai sarana angkutan umum. Adapun metode penelitian yang digunakan dalam penulisan ini adalah penelitian hukum normatif yang merupakanpenelitian hukum yang meletakkan hukum sebagai sebuah bangunan sistem hukum mengenai asas-asas, norma, kaidah dari peraturan perundang-undangan, putusan pengadilan, perjanjian serta doktrin (ajaran). Berdasarkan hasil penelitian ini, maka dapat disimpulkan perlunya membentuk sebuah aturan ataupun kebijakan terkait penggunaan sepeda motor sebagai sarana angkutan umum.
\end{abstract}

Kata Kunci: Angkutan Umum; Kendaraan; Sepeda Motor.

\section{A. Pendahuluan}

Definisi dari transportasi adalah suatu usaha dan kegiatan mengangkut atau membawa barang dan/atau penumpang dari suatu tempat ke tempat lainnya. ${ }^{1}$ Menurut Undang-Undang Republik Indonesia Nomor 22 Tahun 2009 tentang Lalu Lintas dan Angkutan Jalan (selanjutnya disingkat dengan UU LLAJ), angkutan adalah perpindahan orang dan/atau barang dari satu tempat ke tempat lain dengan menggunakan kendaraan di ruanglalu lintas jalan. Transportasi sendiri dibagi menjadi 3, yaitu transportasi darat, laut, dan udara. ${ }^{2}$ Lalu lintas menurut UU LLAJ adalah gerakkendaraan dan orang dalam ruang lalu lintas jalan. Sedangkan pengertian dari ruang lalu lintas jalanyang terdapat dalam UU LLAJ adalah prasarana yang diperuntukkan bagi gerak pindah kendaraan, orang, dan/atau barang yang berupa jalan dan fasilitas pendukung. Lalu lintas dan angkutan jalan harus dikembangkan potensi dan perannya untuk mewujudkan keamanan, kesejahteraan, ketertiban berlalulintas dan angkutan jalan demi mewujudkan pembangunan ekonomi, pengembangan ilmu pengetahuandan teknologi. ${ }^{3}$ Di dalam UU LLAJ

, jenis angkutan terbagi menjadi dua, yaitu angkutan menggunakan kendaraan bermotor dan angkutan menggunakan kendaraan tidak bermotor. Angkutan bermotor adalah moda transportasi yang menggunakan kendaraan bermotor sebagai fasilitas yang bergerak di jalan raya. ${ }^{4}$ Kendaraan bermotor dibagi berdasarkan jenis dan fungsinya. Kendaraan bermotor berdasarkan jenisnya, yaitu sepeda motor, mobil penumpang, mobil bus dan mobil barang. 
Sedangkan kendaraan bermotor berdasarkan fungsinya dibagi dua, yaitu kendaraan bermotor perseorangan dan kendaraan bermotor umum.

Masyarakat di Indonesia sebagian besar sangat bergantung pada angkutan umum karena dilihat dari segi manfaat sangat efektif dan juga bisa berperan dalam mengurangi kemacetan di jalan raya. Salah satu angkutan umum yang sering ditemukan adalah sepeda motor atau yang lebih akrab disebut dengan ojek. Menurut Kamus Besar Bahasa Indonesia (KBBI), definisi ojek adalah alat transportasi sepeda motor ditambangkan dengan memboncengkan penumpang atau penyewanya.

Angkutan dengan sepeda motor merupakan moda transportasi darat yang menggunakan roda dua atau sepeda motor milik pribadi (plat hitam) untuk mengangkut orang/barang dari tempat asal ke tempat tujuan, kemudian dipungut biaya sesuai dengan harga yang telah disepakati oleh kedua belah pihak. Ojek merupakan angkutan umum yang cukup digemari oleh masyarakat di Indonesia karena sifatnya yang fleksibel, dapat menjangkau jalan (gang) sempit yang tidak bisa dilalui oleh jenis angkutan umum yang lain, dapat menghindari kemacetan di jalan dan yang pasti dengan harga yang terjangkau.

Pengoperasian angkutan umum sepeda motor tidak memerlukan izin khusus, seperti uji KIR dan sebagainya, sehingga setiap orang dengan mudah memanfaatkankendaraan (sepeda motor) yang dimilikinya sebagai moda transportasi. Adanya sarana angkutan umum menggunakan sepeda motor menimbulkan perbedaan pendapat bagi kalangan masyarakat umum. Di satu sisi, angkutan umum dengan menggunakan sepeda motor dapat memecahkan masalah karena dianggap sebagai moda transportasi alternative yang cukup fleksibel, namun di sisi lain angkutan ini juga dianggap bermasalah karena tidak ada Undang-Undang atau Peraturan Pemerintah yang mengatur tentang angkutan umum menggunakan sepeda motor.
Dalam Undang-Undang Nomor22

Tahun 2009 tentang Lalu Lintas Angkutan Jalan pada Bab X Bagian Kesatu, menjelaskan bahwa angkutan orang yang menggunakan kendaraan bermotor adalah berupa sepeda motor, mobil penumpang dan bus. Sedangkan pada Bagian Ketiga, menjelaskan bahwa penyelenggaraanangkutan orang dengan kendaraan bermotor umum adalah menggunakan mobil penumpang umum dan mobil bus umum. Sedangkan alat transportasimenggunakan sepeda motor diijinkan sebagai angkutan orang tetapi tidak disebut sebagai bagian dari moda pengangkutan orang dengan kendaraan umum. Dengan kata lain, meskipun keberadaan angkutan umum menggunakan sepeda motor sangat dibutuhkan dikalangan masyarakat, akan tetapi Pemerintah hanya mengijinkan sepeda motor sebagai angkutan orang, bukan beroperasi sebagai secara khusus terkait penggunaan sepeda motor sebagai angkutan umum yang terdapat dalamUU LLAJ, mengakibatkan tidak ada legalitas hukum terkait kedudukan angkutan umum menggunakan sepeda motor sebagai angkutan umum kendaraan bermotor.

Setelah mencermati penjelasan diatas, tentunya akan menarik untuk diteliti secara serius dan mendalam terkait pertimbangan-pertimbangan peran dan kebijakan Pemerintah dan UndangUndang untuk memberikanfasilitas dan legalitas hukum terhadap pengguna angkutan umum menggunakan sepeda motor.Berangkat dari problem riset dan kegelisahan akademik diatas, maka penulis tertarik untuk melakukan penelitian yang sesungguhnya terkait dengan keberadaan dan legalitas hukum terhadap angkutan umum menggunakan sepeda motor. kendaraan umum. Tidak adanya pengaturan

\section{B. Metode Penelitian}

Berdasarkan latar belakang dan permasalahan dalam penulisan ini, maka jenis penelitian yang digunakan dalam 
penulisan ini adalah penelitian hukum normatifatau doktrinal. Penelitian hukum normatif adalah penelitian hukum yang meletakkan hukum sebagai sebuah bangunan sistem hukum mengenai asasasas, norma, kaidah dari peraturan perundang-undangan, putusan pengadilan, perjanjian serta doktrin (ajaran). ${ }^{5}$ Perlunya penelitiannormatif yang dilakukan dalam penulisan ini adalah berawal dari kendaraan bermotor yang digerakkanoleh mesin tetapi dalam UU LLAJ, menyebutkan bahwa sepeda motor tidak termasuk kedalam kendaraan bermotor umum. Sedangkan kenyataan yang kita hadapi sekarang adalah sepeda motor masih sering bahkan semakin banyak yang digunakan sebagai kendaraan bermotor umum. Berawal dari fakta yang terdapat bisa ditarik kesimpulan bahwa adanya kekosongan norma yang mengatur bahwa kendaraan roda dua atau sepeda motor termasuk kedalam angkutan umum. Adapun pendekatan yang digunakan dalam penulisan ini adalah pendekatan kasus (case approach) yang dilakukan dengan cara melakukan telaah terhadap kasus-kasus yang berkaitan dengan isu yang dihadapi yang telah menjadi putusan pengadilan yang telah mempunyai kekuatan hukum yang tetap. ${ }^{6}$ Kemudian pendekatan perundang- undangan (statue approach) yang dilakukan dengan menelaah semua Undang-Undang dan regulasi yang bersangkut paut sesuai hukum yang ditangani. ${ }^{7}$ Dan selanjutnya pendekatan konseptual (conseptual approach) yang digunakan untuk memahami konsep- konsep yang diterapkan dalam menyelesaikan pertentangan norma yang terjadi. Jenis pelayanan angkutan orang dengan kendaraan bermotor umum dalam trayek terdiri dari:

1. Angkutan lintas batas negara Pengertian angkutan lintas batasnegara adalah angkutan dari satukota ke kota lain melewati lintasbatas negara denganmenggunakan mobil bus umum yang terikat dalam trayek

$$
\text { 2. Angkutan antarkota }
$$

antarprovinsi Pengertian angkutan antarkota antarprovinsi adalah angkutan dari satu kota ke kota lain yang melalui daerah kabupaten/kota yang melewati satu daerah provinsi yang terikat dalam trayek.

1. Angkutan antarkota dalamprovinsi Pengertian angkutan antarkotadalam provinsi adalah angkutan dari satu kota ke kota lain antardaerah kabupaten/kota dalam satu daerah provnsi yang terikat dalam trayek.

2. Angkutan perkotaan

Pengertian angkutan perkotaan adalah angkutan dari satu tempatke tempat lain dalam kawasan perkotaan yang terikat dalam trayek. Kawasan perkotaan yangdimaksud berupa:

a. kota sebagai daerah otonom

b. bagian daerah kabupaten yang memiliki ciriperkotaan

c. kawasan yangberada dalam bagian dari dua atau lebihdaerah yang berbatasan langsung dan memiliki ciri perkotaan.

3. Angkutan pedesaan

Yang dimaksud dengan angkutan perdesaan adalahangkutan dari satu tempat ke tempat lain dalam satu daerah kabupaten yang tidak bersinggungan dengan trayek angkutan perkotaan.

Pengangkutan merupakan sarana untuk mencapai suatu tujuan. Sementara itu, kegiatan masyarakat setiap hari berkaitan dengan produksibarang dan jasa untuk mencukupi kebutuhannya yang beraneka ragam. Oleh karena itu, manfaat pengangkutan dapat dilihat dariberbagai segi kehidupan masyarakat sehingga dapat dikelompokanmenjadi:

1. Manfaat ekonomi

2. Manfaat sosial

3. Manfaat politis dan keamanan

4. Manfaat kewilayahan

Alat transportasi memliki beberapa fungsi utama bagi manusia, yaitu:

1. Sebagai alat untuk memudahkan kegiatan manusia sehari-hari.

2. Sebagai alat untuk melancarkan proses perpindahan manusia dan atau barang keperluan manusia.

3. Sebagai media yang dapat membantu pertumbuhan dan perkembangan pembangunan di daerah tertentu. 
4. Sebagai media yang dapat menunjang pertumbuhan dan perkembangan ekonomi nasional melalui bisnis jasa transportasi transportasi

5. Perangkutan/transportasi mem punyai peranan yang sangat penting dan strategis dalam mendukung, mendorong dan menunjang segala aspek kehidupan maupun pertahanan dan keamanan negara. Adapun jenistransportasi transportasi Perangkutan/transportasi mem punyai peranan yang sangat penting dan strategis dalam mendukung, mendorong dan menunjang segala aspek kehidupan maupun pertahanan dan keamanan negara. Adapun jenis jenis transportasi ${ }^{9}$ adalah sebagai berikut:

1. Transportasi udara

2. Transportasi darat, yaitu: bus, kereta (kereta api, komuter, antarkota, kecepatan tinggi, tremdan kereta api ringan), sepeda motor dan ojek, becak serta taxi

3. Transportasi air, yaitu: kapal feridan kapal laut

\section{Legalitas Kendaraan Roda Dua Dalam Penyelenggaraan Angkutan Umum}

Akhir-akhir ini banyak
bermunculan pengusaha di bidang
angkutan umum yang berbasis onlineyang
menggunakan kendaraan rodadua sebagai
armadanya. Munculnya angkutan umum
roda dua atau yang biasa disebut ojek ini,
merupakan salah satu jawaban atas
kebutuhan masyarakat Indonesia akan
transportasi massal yang memadai dan
lebih efisien serta praktis, ditambah lagi
dengan perkembangan penduduk yang ada
di daerah perkotaan akan menyebabkan
bertambah pula penduduk yang menetap
dan bekerja di daerah perkotaan. Hal
tersebut juga memberikan kontribusi
terhadapbertambahnya jumlah kendaraan
yang dikendarai oleh penduduk sebagai
alat transportasi. ${ }^{10}$ Sepeda motor
merupakan angkutan lingkungan, bukan
angkutan perkotaan di lalu lintas jalan

utama, selain itu angkutan umum wajib melakukan pengujian kendaraan bermotor atau yang biasa disebut uji KIR karena terkait dengan keselamatan untuk mengangkut orang, sementara sepeda motor tidak membutuhkan uji tersebut. Pengoperasian angkutan umum sepeda motor tidak memerlukan izin khusus, sehingga setiap orang yang memiliki sepeda motor dengan mudah bisa memanfaatkannya sebagai moda transportasi. Adanya sarana angkutan umum menggunakan sepeda motor menimbulkan perbedaan pendapat bagi kalangan masyarakat umum. Di satu sisi, angkutan umum dengan menggunakan sepeda motor dapat memecahkan masalah karena dianggap sebagai moda transportasi alternatif yang cukup fleksibel, namun di sisi lain angkutan ini juga dianggap bermasalah karena tidak ada Undang-Undang atau Peraturan Pemerintah yang khusus mengatur tentang angkutan umum

menggunakan sepeda motor.Kementerian Perhubungan selanjutnya menyatakan ojek dan transportasi umum berbasis aplikasi dipersilahkan tetap beroperasi sebagai solusi sebagai transportasi publik dapat terpenuhi dengan layak. Berdasarkan uraian permasalahaan diatas maka transportasi roda dua atau ojek tetap dapat beroperasi meskipun bukan termasuk ke dalam jenis kendaran untuk transportasi umum. Oleh karena itu pemerintah diharapkan segera melakukan inovasi dengan memperbaiki sistem maupun sarana transportasi umum yang sudah ada demi kenyamanan dan keselamatan masyarakat umum, mengingat masih banyaknya

tindakan kriminalitas yang terjadi di dalam angkutan umum dan kondisi kelayakan angkutan umum untukberoperasi di jalan raya.

Untuk itu disamping memperbaiki sistem maupun sarana transportasi umum lainnya, pemerintah juga harus segera menetapkan suatu peraturan atau regulasi yang khusus mengatur mengenai transportasi umum kendaraan roda dua ini, agar menjadi jelas legalitas dari kendaraan umum maupun perusahaan yang bergerak 
di bidang angkutan umum yang menggunakan kendaraan roda dua tersebut.

\section{Tanggung Jawab Penyedia Jasa Terhadap Pengguna Jasa Transportasi}

Hukum pengangkutan mengenaltiga prinsip tanggung jawab, yaitu:

1. Tanggung Jawab karenaKesalahan

Setiap pengangkut yang melakukan kesalahan dalam penyelenggaraan pengangkutan harus bertanggung jawabmembayar segala kerugian yang timbul akibat kesalahannya itu.Pihak yang menderita kerugian wajib membuktikan kesalahanpengangkut.

2. Tanggung Jawab karena Praduga Pengangkut dianggap selalu bertanggung jawab atas setiap kerugian yang timbul dari pengangkutan yang diselenggarakannya. Akan tetapi, jika pengangkut dapat membuktikan bahwa ia tidakbersalah, ia dibebaskan dari tanggung jawab membayar gantikerugian itu.

Tanggung Jawab Mutlak Pengangkut harus bertanggungjawab atas setiap kerugian yang timbul dalam pengangkutan yang diselenggarakannya tanpa keharusan pembuktian adatidaknya kesalahan pengangkut. ${ }^{11}$

3. Dalam menjalankan suatu usaha atau bisnis, diperlukan perusahaan asuransi untuk mengatasi resiko usaha atau bisnis tersebut. Mengenai asuransi yang diatur dalam UndangUndang Nomor 2 Tahun 1992 yang telah diganti dalam rangka menyikapi dan mengantisipasi perkembangan industri perasuransian serta perkembangan perekonomian, baik pada tingkat nasional maupun pada tingkat global dengan UndangUndang Nomor 40 Tahun 2014 tentang Perasuransian. ${ }^{12}$ Asuransi adalah perjanjian antara dua pihak, yaitu perusahaan asuransi dan pemegang polis, yang menjadi dasar bagi penerimaan premi oleh perusahaan asuransi sebagai imbalan untuk: Memberikan penggantian kepada tertanggung untuk pemegang polis karena kerugian, kerusakan, biaya yang timbul, kehilangan keuntungan, atau tanggung jawab hukum kepadapihak ketiga yang mungkin diderita tertanggung atau pemegang polis karenaterjadinya suatu peristiwa yang tidak pasti.

4. Memberikan pembayaran yang didasarkan pada meninggalnya tertanggung atau pembayaran yang didasarkan pada hidupnya tertanggung dengan manfaat

yang besarnya telah ditetapkan dan/atau didasarkan pada hasil pengelolaan dana. ${ }^{13}$ Dalam asuransi tanggung jawab, dapat dilihat bahwa oleh karena perbuatan atau aktivitas manusia yang bersifat pribadi atau aktivitas yang berhubungan dengan usaha-usaha ekonomi dapat menimbulkan kerugian- kerugian bagi orang lain atau terhadap benda atau barang orang lain, maka kerugiankerugian ini pun di dalam dunia asuransi dapat menjadi obyek asuransi. $^{14}$

Secara garis besar liability insurance dapat dikelompokkan dalam tiga kelompok besar, yaitu:

1. Business Liability Insurance adalah asuransi tanggung jawab di bidang bisnis, salah satunya asuransi tanggung jawab di bidang bisnis angkutan.

2. Profesional Liability Insuranceadalah asuransi tanggung jawab profesi, seperti profesi dokter, akuntan dan lain-lain.

Personal Liability Insurance adalah asuransi tanggung jawabpribadi ${ }^{15}$. Dalam Undang-Undang Nomor 22 tahun 2009, diatur mengenai asuransi tanggung jawab perusahaan angkutan umum, yaitu:

a. Pasal 189 yang menentukan:

"Perusahaan Angkutan Umumwajib mengasuransikan jawabnya sebagaimana tanggung dimaksud dalam Pasal 188". Adapun 
isi Pasal 188 menentukan:

"Perusahaan

Angkutan Umum wajib mengganti kerugian yang diderita oleh penumpang atau pengirim barang karena lalai dalam melaksanakan pelayananangkutan".

b. Pasal 237"

1) "Perusahaan Angkutan Umum wajib mengikuti program asuransi kecelakaan sebagai wujud tanggung jawabnya atas jaminan asuransi bagi korban kecelakaan".

2) "Perusahaan Angkutan Umum wajib

mengasuransikan orang yang dipekerjakan sebagai awak kendaraan".

Berdasarkan dari uraian yang telah dipaparkan tentang jaminan asuransi jasa angkutan umum diatas, secara tegas dan jelas bahwa aturan- aturan tersebut juga tidak mengatur tentang jasa angkutan kendaraan roda dua. Hal tersebut disebabkan karena memang jasa angkutan umum kendaraan roda dua belum dilegalkan. Dalam hal terjadi kecelakaan lalu lintas yang disebabkan oleh penyedia jasa kendaraan roda dua, baik konvensional maupun online, pengemudi tetap harus bertanggung jawab atas kerugian yang dialami oleh penumpang, Hal itu sesuai dengan Pasal 234 ayat 1 UU Nomor 22 Tahun 2009 yang berbunyi: "Pengemudi, pemilik Kendaraan Bermotor, dan/atau Perusahaan Angkutan Umum bertanggung jawabatas kerugian yang diderita oleh Penumpang dan/atau pemilik barang dan/atau pihak ketiga karena kelalaian Pengemudi". Korban, dalam hal ini adalah penumpang jugabisa mengajukan tuntutan perkarakepada pihak yang berwajib. Untuk itu dalam kecelakaan lalu lintas yang dialami, pengemudi berkewajiban untuk memberikan bantuan kepada korban berupa biaya pengobatan serta membayarkan ganti rugi (yang ditentukan berdasarkan putusan pengadilan) dengan tidak

menggugurkan tuntutan perkara pidana. Adapun sanksi hukum untuk pengemudi yang menyebabkan kecelakaan adalah pidana penjaradan/atau denda yang masa penahanan dan besarnya denda disesuaikan dengan golongan kecelakaan lalu lintas (ringan, sedang, berat) ${ }^{16}$.

\section{Kesimpulan}

Berdasarkan rumusan masalah yang telah dibahas pada bagian bab sebelumnya, maka dapat ditarik kesimpulan sebagai berikut: angkutan dengan sepeda motor merupakan suatu sarana transportasi darat yang menggunakan roda dua milik pribadi (plat hitam) untuk mengangkut orang/barang dari tempat asal ke tempat tujuan, kemudian dipungut biaya sesuai dengan harga yang telah disepakati.Pengoperasian angkutan umum sepeda motor tidak memerlukan izin khusus, sehingga setiap orang yang memliki sepeda motor dengan mudah memanfaatkan kendaraan yang dimilikinya sebagai moda transportasi. Pengoperasian angkutan umum sepeda motor tidak memerlukan izin khusus,sehingga setiap orang yang memiliki sepeda motor dengan mudah bisa memanfaatkannya sebagai moda transportasi. Adanya sarana angkutan umum menggunakan sepeda motor menimbulkan perbedaan pendapat bagi kalangan masyarakat umum. Di satu sisi, angkutan umum dengan menggunakan sepeda motor dapat memecahkan masalah karena dianggap sebagai moda transportasi alternatif yang cukup fleksibel, namun di sisi lain angkutan ini juga dianggap bermasalah karena tidak ada Undang-Undang atau Peraturan Pemerintah yang khusus mengatur tentang angkutan umum menggunakan sepeda motor. Kemudian dengan tidak adanya pengaturan secara khusus terkait penggunaan sepeda motor sebagai angkutan umum yang terdapat dalam UU LLAJ, mengakibatkan tidak ada sanksi hukum bagi seseorang atau perusahaan yang menggunakan sepeda motor sebagai angkutan umum, sehingga sampai sekarang sepeda motor masih tetap eksis dan aktif digunakan sebagai angkutan 
umum, baik di daerah pedesaan maupun di perkotaan dengan jalan raya yang terbilang padat. Akantetapi dalam terjadi kecelakaan yang disebabkan oleh kelalaian pengemudi ojek, maka pengemudi wajib memberikan santunan atau asuransi terhadap penumpang. dengan tidak menggugurkan tuntutan perkara pidana yang dapat diajukan oleh penumpang sebagai korban

\section{Daftar Bacaan}

\section{Buku - Buku}

Abdul Kadir Muhammad, "Hukum Pengangkutan Niaga", Citra Aditya Bakti, Bandung, 2013

Andika Wijaya, Aspek Hukum Bisnis Transportasi Jalan Online, Sinar Grafika, Surabaya, 2016

Herry Gunawan, "Pengantar Transportasi dan Logistik", Raja Grafindo Persada, Jakarta,2014

Mukti Fajar dan Yulianto Achmad, "Dualisme Penelitian Hukum Normatif \& Empiris, Pustaka Pelajar", Yogyakarta, 2010

Nomensen Sinamo, "Hukum Administrasi Negara" (Suatu Kajian Kritis Tentang Birokrasi Negara), Jala Permata Aksara, Jakarta, 2014

\section{Peraturan Perundang- undangan}

Undang-Undang Nomor 22 Tahun 2009 Tentang Lalu Lintas dan Angkutan Jalan

Peter Mahmud Marzuki, "Penelitian Hukum”, Kencana Prenada Media Group, Jakarta, 2011

2. Tesis - Tesis

Achmad Nurmandi, "Manajemen Perkotaan, Teori Organisasi, Perencanaan, Perumahan, Pelayanan dan Transportasi Mewujudkan Kota Cerdas”, JKSG UMY, Yogyakarta, 2014

\section{Jurnal Hukum}

Siti Nurbaiti, Hukum Pengangkutan Darat (Jalan dan Kereta Api),
Universitas Trisakti, Jakarta,2009

\section{Media Daring}

https://id https://id

Wikipedia.org/wiki/Transportasi

Wikipedia.org/wiki/Transporta

si_umum

Undang-Undang Nomor 40 Tahun

2014 Tentang Perasuransian 